\title{
ANALISIS DAMPAK MINAPOLITAN TERHADAP KESEJAHTERAAN MASYARAKAT DI KECAMATAN MUNCAR KABUPATEN BANYUWANGI (Studi Kasus: Desa Tembokrejo dan Kedungrejo)

\author{
Analysis of Minapolitan Impact on the Community Welfare \\ in Muncar Subdistrict Banyuwangi Regency \\ (Case Study: Tembokrejo and Kedungrejo Villages)
}

\author{
*Sri Rahayu Budiani, Putri Kartika Sari, Muthia Hasna Thifaltanti, Regina Lexi Narulita, \\ Reviana Latifah, Prameswari Budi Kusumaningrum, Nourma Linda Isnastuti, \\ Rivan Agung Triawan, dan Dicky Satria Dwiputra \\ Fakultas Geografi, Universitas Gadjah Mada, Indonesia \\ Jl. Kaliurang, Bulaksumur Sinduadi Sleman, Daerah Istimewa Yogyakarta 55281, Indonesia \\ Diterima tanggal: 9 Februari 2019; Diterima setelah perbaikan: 24 Februari 2020; \\ Disetujui terbit: 30 Juni 2020
}

\begin{abstract}
ABSTRAK
Kecamatan Muncar Kabupaten Banyuwangi ditetapkan sebagai kawasan Minapolitan diharapkan mampu meningkatkan kesejahteraan masyarakat baik di dalam kawasan maupun daerah sekitarnya. Masyarakat Desa Kedungrejo dan Tembokrejo mayoritas bekerja pada sektor perikanan, sehingga diasumsikan memiliki dampak langsung dari kebijakan minapolitan. Penelitian ini bertujuan untuk mengetahui perubahan kondisi sosial dan ekonomi masyarakat Kecamatan Muncar sebelum dan sesudah adanya program minapolitan serta mengetahui tingkat kesejahteraan masyarakat berdasarkan kondisi sosial ekonomi tersebut. Penelitian dilakukan pada 23 hingga 27 September 2018 dengan menggunakan metode kualitatif dari hasil wawancara terhadap beberapa pelaku industri, perangkat desa, kepala TPI, dan beberapa nelayan. Analisis dilakukan secara deskriptif kualitatif. Hasil penelitian menunjukkan bahwa kegiatan perindustrian dan sarana prasarana yang menunjang kegiatan perikanan sudah ada sejak tahun 1990-an. Aspek sumberdaya manusia dari segi pendidikan tidak mempengaruhi perkembangan tingkat produksi ikan, sehingga dengan ditetapkannya Kecamatan Muncar sebagai kawasan minapolitan tidak memberikan pengaruh secara signifikan baik kepada kondisi sosial-ekonomi maupun kesejahteraan masyarakat. Rekomendasi yang perlu diterapkan untuk pengembangan program minapolitan di Kecamatan Muncar dapat dilakukan melalui peningkatan sumberdaya manusia seperti penetapan sekolah yang berisi pembelajaran mengenai perikanan dan kelautan, serta peningkatan infrastruktur pendukung. Kedua aspek tersebut perlu ditunjang oleh aspek komitmen daerah sesuai dengan Peraturan Menteri Kelautan dan Perikanan Nomor: PER.12/MEN/2010 tentang Minapolitan.
\end{abstract}

Kata Kunci: Perubahan kondisi sosial-ekonomi; kesejahteraan masyarakat; tingkat produksi ikan; minapolitan; Kecamatan Muncar

\section{ABSTRACT}

Muncar Subdistrict was designated as a Minapolitan area to improve the welfare of the community both within and surrounding areas. It is assumed that Minapolitan policy gives a direct impact on the major livelihood of Kedungrejo and Tambakrejo people in fisheries sector. This study aims to measure the social and economic changes of Muncar community before and after the Minapolitan program as well as to measure the level of the community welfare based on these socio-economic conditions. The study was conducted on 23 to 27 September 2018 based on interviews with industry players, village officials, heads of fish markets and fishers. Data were analyzed using descriptive qualitative method. The results showed that fisheries industry and its facilities have been existed since 1990s. The education level of its community does not affect the fish production. It means that Minapolitan program has not given significant impact to the socio-economic condition and community welfare. It is recommended to improve the capacity of community through learning material at school concerning fisheries management and marine affairs as well as to increase the supporting infrastructure. These two aspects should be encouraged by regional commitment based on Regulation of Minister of Marine Affairs and No: PER.12/MEN/2010 regarding Minapolitan.

Keywords: changes in socio-economic conditions; fish production's level; minapolitan; Muncar subdistrict; public welfare 


\section{PENDAHULUAN}

Indonesia merupakan negara kepulauan yang memiliki wilayah perairan lebih luas dibandingkan dengan wilayah daratannya, yaitu sekitar $70 \%$ atau kurang lebih 5,3 juta $\mathrm{km}^{2}$ (Susmiyati, Hairan \& Asbudi, 2013; Munaf \& Windari, 2015). Kondisi geografis tersebut mendukung perairan Indonesia sebagai negara dengan potensi sumber daya laut yang melimpah untuk dimanfaatkan, salah satunya sumber daya perikanan. Perikanan berkontribusi dalam pertumbuhan ekonomi negara, seperti memiliki peranan penting dalam sumber devisa negara, penyokong penerimaan Pendapatan Asli Daerah (PAD), ataupun berperan dalam pertumbuhan Produk Domestik Bruto (PDB). Subsektor perikanan pada tahun 2016 berkontribusi 19 persen dalam PDB dan berada pada peringkat ketiga terbesar dalam PDB untuk lapangan usaha pertanian, kehutanan, dan perikanan (Badan Pusat Statistik, 2017b).

Salah satu kebijakan pemerintah yang diimplementasikan untuk memanfaatkan potensi perikanan dan kelautan secara optimal untuk mencapai kesejahteraan nelayan (nelayan budidaya dan nelayan penangkap ikan) di berbagai daerah, yaitu berupa pengembangan kawasan minapolitan (Kamuli, 2014). Berdasarkan Peraturan Menteri Kelautan dan Perikanan Republik Indonesia Nomor 12 Tahun 2010 tentang Minapolitan, minapolitan merupakan konsepsi pembangunan ekonomi kelautan dan perikanan berbasis kawasan yang mengusung prinsip terintegrasi, efisien, berkualitas, dan percepatan. Adanya kebijakan atau program minapolitan yang merupakan pilihan dan tanggung jawab pemerintah, diharapkan mampu memberdayakan masyarakat baik secara individu maupun kelompok, menyokong roda perekonomian, terutama dalam bidang perikanan, memberdayakan masyarakat terutama masyarakat nelayan untuk mengurangi kemiskinan, dan menjadi salah satu sarana untuk menjaga kelestarian sumber daya laut (Kamuli, 2014).

Konsep dari Minapolitan harus dilaksanakan sesuai dengan tujuannya, yaitu untuk meningkatkan produksi, produktivitas, dan kualitas untuk kesejahteraan rakyat dan pembangunan ekonomi daerah.Sumber daya sektor perikanan memiliki potensi untuk menjadi penggerak utama perekonomian nasional, akan tetapi pengelolaannya yang belum maksimal menjadikan potensi tersebut belum dapat secara optimal dimanfaatkan sebagai penggerak perekonomian nasional. Orientasi pembangunan dari daratan kelautan perlu dipertimbangkan lebih lanjut agar dapat mendukung terlaksananya konsep Minapolitan (Agustine, 2017).Perubahan orientasi pembangunan yang masih cenderung pada pembangunan daratan ke pembangunan sektor kelautan perlu dilakukan untuk menguatkan peran sektor kelautan dan perikanan sebagai penggerak dari pertumbuhan perekonomian nasional (Salim, 2013).

Kawasan minapolitan yang saat ini dikembangkan salah satunya berada di Kabupaten Banyuwangi, Kecamatan Muncar yang dikhususkan sebagai kawasan pengembangan zona inti minapolitan (Peraturan Daerah Kabupaten Banyuwangi Nomor 08 Tahun 2012). Kecamatan Muncar memiliki Pelabuhan Perikanan Pantai (PPP) yang menjadi pelabuhan perikanan tangkap terbesar kedua di Indonesia (setelah Bagansiapiapi) dan terbesar di Jawa Timur (Dinas Pariwisata dan Kebudayaan Kabupaten Banyuwangi, 2017). Penetapan Kecamatan Muncar sebagai kawasan minapolitan diharapkan mampu meningkatkan pertumbuhan ekonomi Kabupaten Banyuwangi. Kondisi nelayan yang tercermin melalui masyarakat pesisir merupakan hal mendasar dalam memanfaatkan potensi perikanan (Kamuli, 2014). Oleh karena itu, kondisi sosial ekonomi masyarakat berperan penting sebagai salah satu indikator keberhasilan program minapolitan, terutama di Kecamatan Muncar yang ditetapkan sebagai kawasan minapolitan sejak tahun 2012.

Penetapan Kecamatan Muncar sebagai kawasan minapolitan diasumsikan mampu memberikan perubahan positif bagi pembangunan dan kesejahteraan masyarakat di Kecamatan Muncar, khususnya bagi Desa Kedungrejo dan Desa Tembokrejo sebagai daerah penelitian yang dianggap menjadi daerah yang mengalami dampak signifikan terhadap penetapan kawasan minapolitan. Hal tersebut dikarenakan kedua daerah tersebut memiliki penduduk yang mayoritas bekerja di sektor perikanan. Dengan demikian, perlu dilakukannya penelitian mengenai dampak penetapan kawasan minapolitan terhadap kesejahteraan masyarakat yang dilihat dari aspek sosial maupun ekonomi di Kecamatan Muncar (Desa Kedungrejo dan Desa Tembokrejo). Penelitian ini bertujuan untuk mengetahui perubahan kondisi sosial dan ekonomi masyarakat Kecamatan Muncar sebelum dan sesudah adanya program minapolitan serta mengetahui tingkat kesejahteraan masyarakat Kecamatan Muncar berdasarkan kondisi sosial ekonomi tersebut. 


\section{METODOLOGI}

\section{Lokasi dan Waktu Penelitian}

Penelitian dilakukan pada 23 hingga 27 September 2018 di Desa Tegalrejo dan Kedungrejo, Kecamatan Muncar, Kabupaten Banyuwangi, Jawa Timur (Gambar 1). Berdasarkan data Badan Pusat Statistik Kabupaten Banyuwangi (2017), $33 \%$ pekerjaan utama di Desa Kedungrejo dan 40\% pekerjaan utama di Desa Tembokrejo berada di sektor perikanan. Berdasarkan data tersebut, diketahui bahwa Desa Kedungrejo dan Desa Tembokrejo merupakan desa dengan pekerjaan pada sektor perikanan terbesar di Kecamatan Muncar. Desa Kedungrejo telah dikenal sebagai kawasan industri perikanan sebelum ditetapkannya Kecamatan Muncar sebagai Kawasan Minapolitan, sementara Desa Tembokrejo dipilih karena sebagian besar penduduk di desa ini bekerja sebagai nelayan dan bekerja dalam industri rumah tangga pengolahan ikan hasil tangkap.

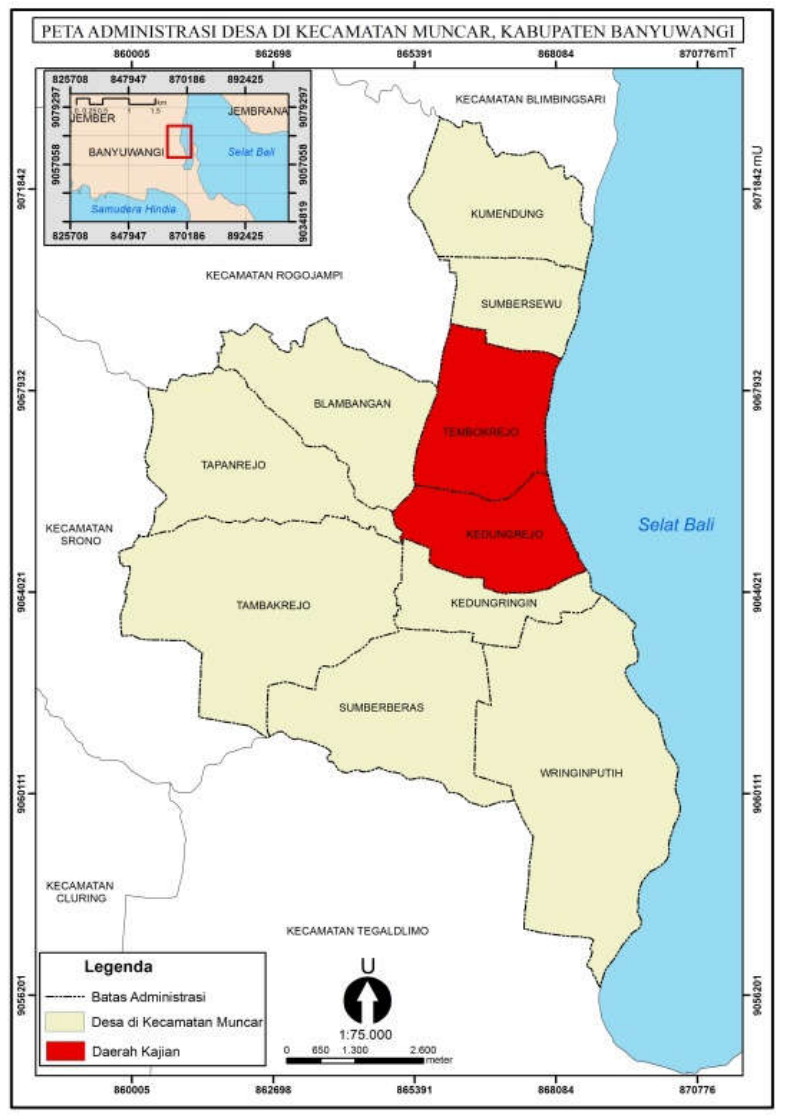

Gambar 1. Peta Daerah Kajian (Desa Tembokrejo dan Desa Kedungrejo).

Figure 1. Map of Research Area (Tembokrejo and Kedungrejo Village).

Sumber: Badan Informasi Geospasial (BIG), 2018/

Source:Geospatial Information Agency BIG), 2018

\section{Jenis dan Metode Pengambilan Data}

Desain penelitian ini menggunakan metode kualitatif menurut Ibrahim (2015) untuk mengetahui kondisi sosial dan ekonomi masyarakat yang terlibat langsung dalam kegiatan perikanan, selanjutnya data dianalisis menggunakan analisis deskriptif kualitatif.Jenis data yang digunakan yaitu data sekunder.Penelitian ini mengkaji tentang kesejahteraan masyarakat yang berada pada kawasan minapolitan. Sementara konsep kesejahteraan yang digunakan dalam penelitian ini, yaitu dari Badan Pusat Statistik (2015) yang meliputi berbagai aspek. Aspek yang digunakan untuk menentukan kesejahteraan masyarakat Desa Tembokrejo dan Desa Kedungrejo dalam penelitian ini adalah aspek sosial dan ekonomi sebagai indikator untuk mengetahui dampak dari adanya program minapolitan. Aspek sosial yang digunakan diantaranya adalah tingkat pendidikan nelayan dan buruh pabrik, sedangkan aspek ekonomi yang digunakan diantaranya adalah sarana dan prasarana seperti pasar ikan dan industri, pendapatan, serta penyerapan tenaga kerja dari kegiatan perikanan di lokasi kajian.

Pengumpulan data primer dilakukan dengan eksplorasi melalui wawancara mendalam (in depth interview) yang menyesuaikan panduan oleh Ibrahim (2015), pada beberapa pihak meliputi Kepala Seksi Operasional Unit Pelaksana Teknis (UPT) Pelabuhan dan Pengelolaan Sumber daya Kelautan dan Perikanan Muncar, perangkat Desa Tembokrejo dan Desa Kedungrejo, kepala Tempat Pelelangan Ikan (TPI) Brak Kalimoro di Kedungrejo dan kepala TPI Satelit di Tembokrejo, pelaku industri perikanan, dan nelayan setempat. Sarana dan prasarana dalam kegiatan perikanan. Pertanyaan umum dalam wawancara meliputi pengetahuan tentang minapolitan dan perbedaan sebelum dan sesudah adanya minapolitan, kendala dalam perikanan, siapa saja pelaku dalam perikanan, serta keterlibatan pemerintah dalam mengenalkan minapolitan ditanyakan kepada semua informan untuk mendapatkan informasi dari sudut pandang yang berbeda. Sementara pertanyaan tambahan yang diajukan kepada pelaku perikanan adalah sebagai berikut.

a). Buruh pabrik dan distributor ikan

1. Jenis produksi pabrik

2. Asal suplai ikan

3. Tujuan lokasi pemasaran

4. Modal 
5. Tenaga kerja (asal, pendidikan, pendapatan)

6. Limbah

b). Nelayan

1. Perbedaan produksi ikan

2. Jenis ikan yang ditangkap

3. Perbedaan harga ikan

4. Tujuan penjualan ikan dan integrasi dengan industri setempat

5. Ketercukupan pendapatan dari hasil nelayan

6. Tingkat pendidikan dan asal nelayan

7. Modal penangkapan ikan

Pengumpulan data sekunder juga dilakukan untuk mendukung analisis dari hasil wawancara yang telah dilakukan. Data sekunder yang digunakan dalam penelitian ini yaitu:

1. Data pekerjaan utama menurut sektor Desa Kedungrejo tahun 2015

2. Data pekerjaan utama menurut sektor Desa Tembokrejo tahun 2015

3. Data produksi ikan di Kecamatan Muncar tahun 2008-2015

\section{Metode Analisis}

Pengolahan data dilakukan dengan membuat transkrip wawancara mendalam ke dalam Microsoft Word. Analisis terhadap transkrip wawancara dilakukan secara deskriptif kualitatif dan bersifat subjektif yang merujuk pada Bastian, Winardi, \& Fatmawati (2018); sedangkan data sekunder diolah dengan membuat tabel untukmengetahui perubahan atau dinamika dari tahun ke tahun. Analisis kondisi sosial dan ekonomi dilakukan untuk mengetahui perubahan terhadap kondisi sosial dan ekonomi masyarakat perikanan di Desa Kedungrejo dan Desa Tembokrejo sebelum dan setelah penetapan Kawasan Minapolitan. Analisis kondisi sosial yang dibandingkan yaitu pada indikator pendidikan antar Desa Kedungrejo dan Desa Tembokrejo, sedangkan analisis kondisi ekonomi yang dibandingkan adalah indikator sarana prasarana, pendapatan per kapita, dan penyerapan tenaga kerja di Desa Kedungrejo dan Desa Tembokrejo. Kesejahteraan masyarakat dilihat dari indikator-indikator yang diturunkan dari aspek sosial-ekonomi di Desa Kedungrejo dan Tembokrejo. Pengambilan kesimpulan dari transkrip dengan mengacu pada Bastian et al. (2018).

\section{HASIL DAN PEMBAHASAN}

Kesejahteraan masyarakat menurut Badan Pusat Statistik (2017a) dapat ditinjau dari berbagai indikator, diantaranya diturunkan dari aspek sosial dan ekonomi masyarakat. Program minapolitan ditujukan untuk meningkatkan kesejahteraan masyarakat pesisir melalui upaya meningkatkan produksi perikanan, produktivitas kerja masyarakat nelayan salah satunya dengan pemberian asuransi keselamatan kerja, kualitas kesejahteraan masyarakat, dan pembangunan ekonomi daerah. Contoh nyata program minapolitan yang telah diterapkan di Kawasan Minapolitan Muncar diantaranya adalah pembangunan pelabuhan pendaratan ikan (PPI) di Desa Kedungrejo pada 2012. Akan tetapi, fasilitas tersebut tidak diiringi dengan peningkatan fasilitas lain yang mendukung program minapolitan, seperti peningkatan kualitas kapal atau pengadaan alat tangkap ikan yang memadai. Kondisi tersebut merupakan salah satu akibat tidak efektifnya program minapolitan yang diterapkan di Kawasan Minapolitan Muncar.

\section{Aspek Sosial Masyarakat}

Program Minapolitan merupakan kegiatan yang kompleks dan tidak hanya terfokus pada usaha kegiatan perikanan, namun aspek sosial masyarakat juga perlu diperhatikan sebagai salah satu pemegang kendali aktivitas minapolitan. Berdasarkan hasil wawancara mendalam dengan beberapa informan baik di Desa Tembokrejo maupun Desa Kedungrejo, masyarakat yang bekerja sebagai buruh pabrik sebagian besar merupakan tamatan SLTA sederajat. Hal tersebut karena pabrik membutuhkan sumber daya manusia yang mempunyai skill tertentu sehingga buruh dengan pendidikan yang tinggi dianggap lebih mempunyai skill yang mumpuni daripada yang berpendidikan rendah. Sementara itu, masyarakat yang bermatapencaharian sebagai nelayan cenderung hanya tamatan SD hingga SLTP sederajat, bahkan ada yang tidak mengenyam pendidikan. Hal tersebut dikarenakan adanya tradisi keluarga yang lebih memilih bekerja menjadi nelayan daripada bersekolah karena dapat menghasilkan uang dan bisa langsung membantu perekonomian keluarga. Sejalan dengan penelitian Wiratama (2016) yang memaparkan bahwa bagi masyarakat desa yang penting seorang anak mempunyai kemampuan bertani atau bersawah dan berkebun. Pola pemikiran tersebut perlu mendapat perhatian karena apabila terus berlanjut maka tingkat pendidikan keluarga nelayan tidak akan meningkat. Kondisi dari tingkat pendidikan penduduk Desa Tembokrejo disajikan pada Tabel 1. 
Tabel 1. Tingkat Pendidikan Penduduk Desa Tembokrejo Tahun 2012-2017.

Table 1. Education Level of Tembokrejo Village in 2012-2017.

\begin{tabular}{|c|c|c|c|c|c|c|}
\hline Tahun/Year & 2012 & 2013 & 2014 & 2015 & 2016 & 2017 \\
\hline $\begin{array}{l}\text { Tamat SD/Graduated from } \\
\text { Elementary School }\end{array}$ & 4.283 & 14.116 & 4.283 & 6.582 & 3.629 & 6.311 \\
\hline $\begin{array}{l}\text { Tamat SMP/Graduated from Junior } \\
\text { High School }\end{array}$ & 8.770 & 5.128 & 8.770 & 6.582 & 6.582 & 6.432 \\
\hline $\begin{array}{l}\text { Tamat SMA/Graduated from Senior } \\
\text { High School }\end{array}$ & 6.647 & 3.078 & 6.647 & 7.831 & 5.831 & 8.917 \\
\hline
\end{tabular}

Sumber: Profil Desa Tembokrejo, 2018/Source: Village Profile of Tembokrejo, 2018

Struktur sosial nelayan yang diketahui berdasarkan hasil wawancara serta sejalan dengan penelitian Saleha (2013) yaitu nelayan diklasifikasikan menjadi nelayan pemilik kapal dan nelayan buruh (pekerja). Nelayan pemilik kapal sebagai strata pertama merupakan nelayan yang mempunyai kepemilikan aset berupa kapal dan peralatan tangkap, tetapi umumnya membutuhkan pinjaman modal karena tidak cukup kebutuhan finansialnya untuk melakukan operasional melaut. Pinjaman modal didapatkan dari Koperasi Unit Desa (KUD) yang ada di Muncar. Nelayan buruh sebagai strata kedua merupakan nelayan yang ikut bekerja pada nelayan pemilik kapal. Nelayan buruh hanya memiliki modal tenaga, namun tidak memiliki modal dari segi finansial, alat tangkap ikan ataupun kapal. Apabila telah selesai melaut, nelayan pemilik kapal dan nelayan buruh akan melakukan proses pembagian hasil tangkapan sesuai kesepakatan.

Pola kerja atau aktivitas penangkapan rata-rata dilakukan dengan cara bermalam 3-5 hari di laut, meskipun ada sebagian nelayan yang hanya melaut dalam satu hari. Pembagian hasil berbanding lurus dengan pola kerja, karena penghasilan akan didapatkan sesuai dengan aktivitas penangkapan ikan. Intensitas ikan yang didapat akan lebih besar apabila penangkapan ikan lebih sering, meskipun sumberdaya yang ada penuh dengan ketidakpastian.

Tingkat pendidikan nelayan yang rendah berpengaruh terhadap penerimaan programprogram yang diimplementasikan oleh pemerintah. Hasil wawancara dengan salah satu anak ketua kelompok nelayan di Desa Kedungrejo menyatakan bahwa masih banyak nelayan yang tidak menjalankan program-program yang diarahkan oleh pemerintah karena ketidakpahaman nelayan mengenai program-program tersebut, salah satunya program Minapolitan yang dicanangkan oleh Kementerian Kelautan dan Perikanan Republik
Indonesia. Salah satu kondisi nyata yang ditemukan di lapangan, yaitu kegiatan pembangunan dan pengembangan kawasan Minapolitan Muncar yang dianggap masih di bawah target. Sebagian besar masyarakat nelayan hanya mengandalkan sosialisasi-sosialisasi dari pemerintah tanpa adanya inovasi yang ingin dikembangkan untuk meningkatkan produktivitas aktivitas minapolitan.

Struktur sosial yang ada pada kelompok nelayan Muncar bersifat struktur sosial terbuka. Struktur sosial terbuka memungkinkan terjadinya mobilitas vertikal baik berupa naik maupun turun. Nelayan buruh naik strata sosialnya menjadi nelayan pemilik kapal karena modal telah mencukupi untuk membeli kapal sehingga beroperasi secara mandiri, ataupun nelayan pemilik kapal yang turun strata menjadi nelayan buruh karena asetnya dijual. Budaya statis seperti nelayan buruh akan terus menjadi nelayan buruh, atau nelayan pemilik kapal akan selalu menjadi nelayan pemilik kapal, tidak terjadi di Kecamatan Muncar karena struktur sosial bersifat fleksibel dalam memberikan ruang gerak bagi mobilitas nelayan yang berakitivitas.

Berdasarkan hasil observasi di lapangan dapat diketahui bahwa adanya program minapolitan belum memberikan dampak positif yang nyata terhadap tingkat pendidikan masyarakat Desa Kedungrejo dan Desa Tembokrejo. Kondisi sebelum adanya minapolitan maupun setelah adanya minapolitan, tingkat pendidikan masyarakat tidak banyak berubah. Kondisi yang demikian memerlukan perhatian khusus dari pemerintah untuk terus memberikan sosialisasi mengenai pentingnya pendidikan atau pembuatan sekolah yang berbasis pengetahuan ilmu manajemen perikanan dan kelautan agar setelah lulus dari sekolah menengah atau sekolah kejuruan dapat diaplikasikan langsung saat melaut. Tingkat pendidikan mampu menjadi akselerator dalam berjalannya program minapolitan karena dengan 
pengetahuan yang tinggi akan meningkatkan kemampuan masyarakat dalam bekerja sehingga produktivitas meningkat dan pada akhirnya program minapolitan dapat berjalan dengan baik.

\section{Aspek Ekonomi Masyarakat Sarana dan Prasarana}

Sarana dan prasarana berupa industri pengolahan dan pasar ikan atau Tempat Pelelangan Ikan (TPI) yang ada di Desa Kedungrejo dan Desa Tembokrejo. Desa Kedungrejo memiliki satu TPI, yaitu TPI Brak Kalimoro (Gambar 2), sedangkan Desa Tambakrejo memiliki satu TPI juga, yaitu TPI Satelit (Gambar 3). TPI yang ada di lokasi kajian telah ada sejak era 1990-an, sehingga menunjukkan bahwa sarana dan prasarana telah ada jauh sebelum adanya program minapolitan yang dimulai pada tahun 2013. Fasilitas-fasilitas lain yang menunjang kegiatan perikanan seperti rumah sewa untuk pengolahan ikan kering, freezer, timbangan, box, dan alat tangkap ikan telah diberikan oleh pemerintah sebelum adanya program minapolitan. Keberadaan industri pengolahan ikan juga sudah ada sebelum adanya program Minapolitan diterapkan.

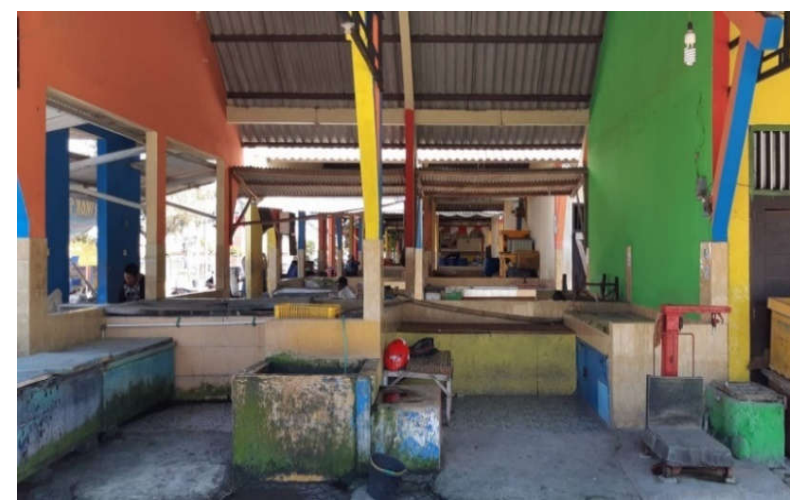

Gambar 2. TPI Brak, Kalimoro, Desa Kedungrejo. Figure 2. TPI Brak on Kalimoro, Kedungrejo Village.

Kondisi sarana prasarana di Desa Kedungrejo dan Desa Tambakrejo sebelum dan sesudah kebijakan minapolitan tidak mengalami perubahan yang signifikan. Hal tersebut ditunjukkan dengan bantuan pemerintah yang sudah ada dari sebelum adanya program minapolitan, seperti bantuan yang diusulkan melalui proposal. Dampak kebijakan minapolitan terhadap sarana prasarana di Desa Kedungrejo hanya terwujud dengan dibangunnya Pelabuhan Pendaratan Ikan di Desa Kedungrejo pada tahun 2012.

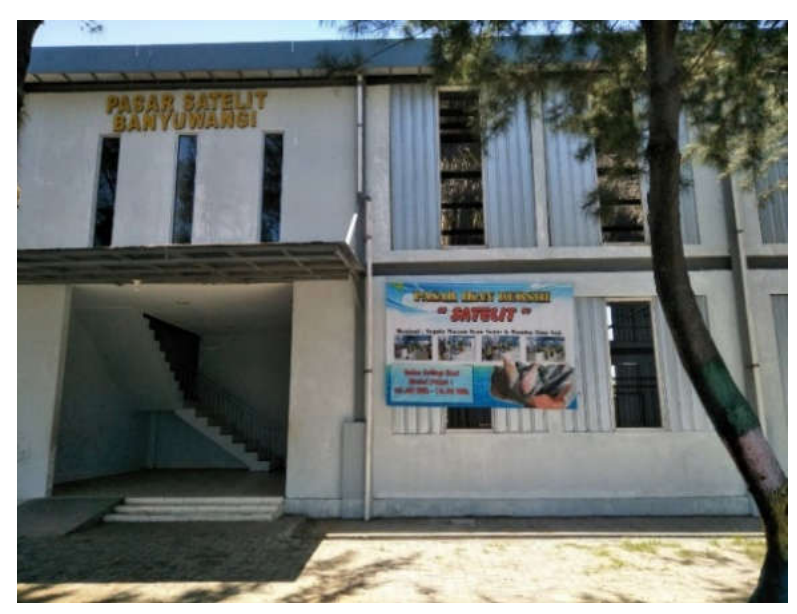

Gambar 3. TPI Satelit Desa Tembokrejo. Figure 3. TPI Satelit on Tembokrejo Village.

\section{Pendapatan}

Pendapatan per kapita penduduk Desa Kedungrejo dan Tembokrejo pada tahun 2011 hingga 2017 seperti pada Tabel 2 menunjukkan bahwa pendapatan per kapita Desa Tembokrejo cenderung konstan dan hanya mengalami kenaikan yang tidak signifikan pada tahun 2015. Sementara itu, pendapatan per kapita Desa Kedungrejo mengalami kenaikan yang signifikan pada tahun 2013 dan penurunan yang cukup signifikan pada tahun 2017. Hal tersebut dapat menunjukkan Desa Kedungrejo sangat dipengaruhi oleh penetapan Kecamatan Muncar sebagai kawasan minapolitan pada tahun 2012. Adanya sistem regulasi yang baru dan ditetapkannya Muncar sebagai kawasan prioritas perikanan secara tidak langsung dapat berpengaruh terhadap supply chain ataupun kegiatan perekonimian yang meliputi proses produksi, konsumsi, dan distribusi.

Pendapatan masyarakat di Desa Kedungrejo dan Tembokrejo dipengaruhi jenis pekerjaannya. Berdasarkan hasil wawancara, buruh pabrik memiliki pendapatan yang bergantung dengan banyaknya proses industri perikanan yang dikerjakan. Semakin sedikit ikan yang dapat dijadikan input, maka proses akan semakin jarang dan pendapatan akan semakin kecil. Sebaliknya, jika industri mendapatkan banyak input ikan, maka proses yang berlangsung akan semakin banyak dan pendapatan yang didapat buruh semakin besar. Sama halnya dengan buruh pabrik, pedagang ikan juga bergantung dengan banyaknya ikan yang didapat nelayan. Semakin banyak ikan maka pendapatan akan semakin besar, karena ikan yang dijual akan semakin banyak pula. Jika nelayan Muncar hanya mendapat sedikit ikan, 
maka pedagang ikan mengambil ikan dari daerah lain dan membutuhkan modal yang lebih banyak. Maka dari itu, keuntungan pedagang ikan akan semakin kecil apabila ikan yang ditangkap nelayan Muncar semakin sedikit. Keterbatasan kemampuan modal usaha menjadi salah satu faktor internal yang mempengaruhi kesejahteraan nelayan (Kusnadi, 2002 dalam Rosni, 2017). Pendapatan nelayan juga sangat bergantung terhadap produksi ikan, menurunnya produksi ikan tangkap menyebabkan pendapatan nelayan rendah.

Pendapatan per kapita Desa Kedungrejo pada tahun 2013 mengalami peningkatan secara ekstrim, yaitu dari Rp800,000.00 menjadi Rp5,750,000.00 per kapita. Penetapan kawasan minapolitan pada Kecamatan Muncar di tahun 2012 menghasilkan dampak positif pada indicator pendapatan, meskipun hanya pada Desa Kedungrejo. Peningkatan tersebut didukung oleh sarana prasarana yang berubah berupa penambahan Pelabuhan Pendaratan Ikan di Desa Kedungrejo.

\section{Penyerapan Tenaga Kerja}

Tenaga kerja yang ada di Desa Kedungrejo dan Desa Tembokrejo dibagi menjadi buruh, nelayan, pedagang ikan, pengelola ikan asin ataupun pemilik UMKM. Tenaga kerja yang ada di kedua desa ini tidak hanya berasal dari desa tersebut, melainkan terdapat pula banyak tenaga kerja yang berasal dari luar desa bahkan dari luar Kecamatan Muncar. Berdasarkan hasil wawancara, informan menyebutkan bahwa buruh pabrik yang datang untuk bekerja biasanya menunggu dipanggil

Tabel 2. Pendapatan Per Kapita dari Sektor Perikanan di Desa Kedungrejo dan Desa Tembokrejo Tahun 2011-2017.

Table 2. Per Capita Income of Fishery Sector in Kedungrejo Village and Tembokrejo Village in 2011-2017.

\begin{tabular}{crc}
\hline Tahun/Year & $\begin{array}{c}\text { Pendapatan Perkapita Desa } \\
\text { Kedungrejo/Per Capita Income of } \\
\text { Kedungrejo Village }\end{array}$ & $\begin{array}{c}\text { Pendapatan Perkapita Desa } \\
\text { Tembokrejo/Per Capita Income of } \\
\text { Tembokrejo Village }\end{array}$ \\
\hline 2011 & Rp800,000.00 & Rp800,000.00 \\
2012 & Rp800,000.00 & Rp850,000.00 \\
2013 & Rp5,750,000.00 & Rp850,000.00 \\
2014 & TA & $R p 850,000.00$ \\
2015 & TA & $R p 1,000,000.00$ \\
2016 & Rp5,750,000.00 & Rp1,000,000.00 \\
2017 & Rp2,100,000.00 & Rp1, 000,000.00 \\
\hline
\end{tabular}

Sumber: Profil Desa Kedungrejo dan Tembokrejo Tahun 2012-2018/

Source: Village Profile Kedungrejo and Tembokrejo Village in 2012-2018

Tabel 3. Struktur Mata Pencaharian Menurut Sektor (Perikanan).

Table 3. Structure of Livelihoods by Sector (Fishery).

\begin{tabular}{|c|c|c|c|c|c|c|c|c|}
\hline \multirow{2}{*}{\multicolumn{2}{|c|}{$\begin{array}{ll}\text { a. Desa Kedungrejo/ } \\
\text { Kedungrejo Village }\end{array}$}} & 2011 & 2012 & 2013 & 2014 & 2015 & 2016 & 2017 \\
\hline & & & & & & & & \\
\hline \multicolumn{2}{|r|}{1 Nelayan/Fisher's } & 6,392 & 6,392 & 11,057 & TA & TA & 11,057 & 8,057 \\
\hline 2 & $\begin{array}{l}\text { Pemilik usaha perikanan/ } \\
\text { Owner of fisheries business }\end{array}$ & 63 & 63 & 219 & TA & TA & 219 & 219 \\
\hline \multirow[t]{2}{*}{3} & $\begin{array}{l}\text { Buruh usaha perikanan/ } \\
\text { Fisheries workers }\end{array}$ & 6,329 & 6,329 & 4,448 & TA & TA & 4,448 & 4,448 \\
\hline & $\begin{array}{l}\text { b. Desa Tembokrejo/ } \\
\text { Tembokrejo Village }\end{array}$ & & & & & & & \\
\hline \multicolumn{2}{|r|}{1 Nelayan/Fisher's } & 4,095 & 16,170 & 16,170 & 3,785 & 4,000 & 4,000 & 4,000 \\
\hline \multicolumn{2}{|r|}{$\begin{array}{l}2 \text { Pemilik usaha perikanan/ } \\
\text { Owner of fisheries business }\end{array}$} & 375 & 4,899 & 4,899 & 1,157 & 1,540 & 1,540 & 1,540 \\
\hline 3 & $\begin{array}{l}\text { Buruh usaha perikanan/ } \\
\text { Fisheries workers }\end{array}$ & 7,000 & 11,271 & 11,271 & 2,413 & 12,500 & 12,500 & 12,500 \\
\hline
\end{tabular}

Sumber: Profil Desa Kedungrejo dan Tembokrejo Tahun 2011-2017/

Source: Village Profile Kedungrejo and Tembokrejo Village in 2011-2017 
oleh pabrik. Hal ini karena tidak setiap saat input ikan untuk produksi pabrik ada, sehingga apabila input ikan tersedia, maka buruh akan dipanggil untuk bekerja. Kondisi struktur mata pencaharian berdasarkan sektor perikanan di Desa Kedungrejo dan Tembokrejo dapat dilihat pada Tabel 3, sedangkan kondisi perikanan di pelabuhan dan pengelolaan sumberdaya kelautan dan perikanan Muncar dapat dilihat pada Tabel 4.

Adanya penurunan produksi ikan tangkap yang tentunya merugikan banyak pihak, terutama para nelayan dan industri. Penurunan produksi ikan menjadikan buruh pabrik banyak yang menganggur dikarenakan industri tersebut akan berhenti bekerja apabila input ikan kurang, sehingga banyak terjadi alih profesi terutama buruh pabrik menjadi buruh bangunan, petani bahkan merantau ke luar kota. Industri pengolahan sangat memerlukan ikan dalam jumlah yang banyak sebagai input dari produksi. Menurunnya jumlah produksi ikan dari Kecamatan Muncar membuat banyak industri menggunakan ikan impor sebagai input produksi. Hal tersebut turut memberikan kerugian bagi nelayan setempat yang tentunya tidak bisa memasok ikan bagi industri lagi.

Dampak program minapolitan terhadap kesejahteraan masyarakat dalam segi penyerapan tenaga kerja juga belum memiliki dampak yang positif. Jumlah nelayan terus mengalami penurunan dalam beberapa tahun terakhir. Penurunan tersebut berkaitan dengan jumlah produksi ikan yang terus menurun pula. Jumlah nelayan yang semakin menurun diakibatkan oleh musim paceklik. Musim panceklik yang berkepanjangan akibat perubahan iklim membuat nelayan kehilangan mata pencaharian. Angin dan gelombang tinggi yang tidak terprediksi sering menyebabkan nelayan tidak melaut. Buruknya iklim juga berpengaruh pada penurunan pendapatan dan kesejahteraan sosial rumah tangga nelayan (Fatimah, Sunartomo, \& Mustapit, 2014).

Berdasarkan hasil tinjauan dari aspek sosial maupun ekonomi, dapat dikatakan bahwa adanya program minapolitan terhadap kesejahteraan masyarakat yang ditinjau dari berbagai indikator tersebut masih belum memberikan dampak yang positif. Hal ini karena, salah satu tujuan dari adanya program Minapolitan tidak terwujud karena produksi dan produktivitas perikanan tidak berhasil meningkat. Selain itu, salah satu karakteristik kawasan minapolitan adalah memberikan dampak positif bagi daerah sekitarnya, namun karakteristik tersebut belum terwujud secara konsisten karena banyak nelayan yang beralih profesi akibat berkurangnya produksi ikan.

\section{KESIMPULAN DAN REKOMENDASI KEBIJAKAN}

\section{Kesimpulan}

Hasil penelitian menunjukkan bahwa tidak ada perubahan yang signifikan pada kondisi sosial dan kondisi ekonomi masyarakat Muncar antara sebelum dan setelah ditetapkannya Kecamatan Muncar sebagai Kawasan Minapolitan. Kondisi sosial dilihat dari pendidikan, tidak mengalami perubahan secara signifikan baik sebelum maupun sesudah minapolitan. Kondisi ekonomi dilihat dari sarana prasarana, pendapatan, dan penyerapan tenaga kerja. Sarana prasarana yang berubah hanya Pelabuhan Pendaratan Ikan di Desa Kedungrejo yaitu tepat sebelum adanya penetapan Kawasan Minapolitan, sedangkan industri tidak berubah secara signifikan karena sudah terbangun sejak tahun 1990-an. Pendapatan tidak menentu serta menurunnya produksi ikan, diikuti dengan jumlah nelayan yang semakin sedikit dan beralih profesi ke sektor lain.

Kesejahteraan masyarakat dilihat dari indikator-indikator yang diturunkan dari aspek sosial-ekonomi di Desa Kedungrejo dan Tembokrejo masih belum dipengaruhi secara positif oleh adanya program Minapolitan. Hal ini menunjukkan bahwa program Minapolitan di Kecamatan Muncar sejak pertama kali diresmikan belum mencapai target untuk menyejahterakan masyarakat khususnya masyarakat yang bekerja pada sektor perikanan.

Tabel 4. Data Perikanan di Pelabuhan dan Pengelolaan Sumberdaya Kelautan dan Perikanan Muncar Tahun 2008-2017.

Table 4. Fisheries Data in Ports and Marine Resources and Fisheries of Muncar in 2008-2017.

\begin{tabular}{lrrrrrrrrrr}
\hline \multicolumn{1}{c}{ Mata Pencaharian } & $\mathbf{2 0 0 8}$ & $\mathbf{2 0 0 9}$ & $\mathbf{2 0 1 0}$ & $\mathbf{2 0 1 1}$ & $\mathbf{2 0 1 2}$ & $\mathbf{2 0 1 3}$ & $\mathbf{2 0 1 4}$ & $\mathbf{2 0 1 5}$ & $\mathbf{2 0 1 6}$ & $\mathbf{2 0 1 7}$ \\
\hline Pedagang Ikan/Fish seller & 109 & 111 & 102 & 65 & 84 & 70 & 75 & 76 & 75 & 72 \\
Pengelola Ikan Asin/Salted fish seller & 53 & 24 & 24 & 52 & 47 & 45 & 45 & 45 & 34 & 52 \\
\hline
\end{tabular}

Sumber: Data UPT P2SKP Muncar, 2018/Source: Data from UPT P2SKP at Muncar, 2018 


\section{Rekomendasi Kebijakan}

Rekomendasi yang diperlukan untuk perbaikan dan pengembangan program minapolitan dapat dikonsentrasikan melalui tiga aspek, yaitu sumberdaya manusia, infrastruktur pendukung, dan komitmen daerah. Peningkatan sumberdaya manusia untuk mengembangkan program minapolitan dapat dilakukan dengan menerapkan sekolah perikanan. Sekolah perikanan mampu menjadi sebuah akselerator bagi pemuda di Kecamatan Muncar dalam meningkatkan kemampuan dan wawasan dalam bidang perikanan sebelum terlibat langsung dalam lingkungan kerja bidang perikanan di Kecamatan Muncar. Melalui sekolah perikanan, mampu membantu dalam mengembangkan program minapolitan di Kecamatan Muncar.

Selain sumberdaya manusia, pengembangan program minapolitan juga perlu dilakukan melalui peningkatan infrastruktur pendukung. Infrastruktur pendukung yang mampu membantu dalam peningkatan produksi dan pengolahan ikan di Kecamatan Muncar, seperti pembangunan pelabuhan, rehabilitasi pasar, dan teknologi industri. Infrastruktur pendukung ini juga diharapkan mampu memperbaiki pengolahan komoditas unggulan di Kecamatan Muncar, yaitu ikan lemuru sehingga produksi yang dihasilkan juga akan meningkat dan memiliki kualitas yang baik. Fasilitas pendukung juga diharapkan mampu meningkatkan branding dan pemasaran dari hasil pengolahan komoditas unggulan.

Komitmen daerah dapat diterapkan melalui peran pemerintah daerah yang perlu terlibat secara langsung dalam pengembangan program minapolitan di Kecamatan Muncar. Hal-hal yang perlu dilakukan adalah membuat kebijakankebijakan terkait pengembangan program minapolitan, sosialisasi kepada masyarakat, dan kegiatan lainnya yang pada akhirnya juga perlu melakukan proses monitoring dan evaluasi terhadap kebijakan-kebijakan yang telah diterapkan sehingga program minapolitan di Kecamatan Muncar dapat terus berkembang dan berlangsung secara berkelanjutan.

\section{UCAPAN TERIMA KASIH}

Penulis mengucapkan terimakasih pada Kepala Desa Tembokrejo dan Kepala Desa Kedungrejo atas perizinan dan akses data yang diberikan. Terimakasih kami sampaikan kepada
Kepala Seksi Operasional Unit Pelaksana Teknis (UPT) Pelabuhan dan Pengelolaan Sumberdaya Kelautan dan Perikanan Muncar, perangkat desa Desa Tembokrejo dan Desa Kedungrejo, kepala Tempat Pelelangan Ikan (TPI) Brak Kalimoro di Kedungrejo dan kepala TPI Satelit di Tembokrejo, pelaku industri perikanan, dan nelayan setempat yang telah bersedia untuk diwawancarai sehingga penulis dapat memperoleh informasi yang dibutuhkan. Penulis juga mengucapkan terimakasih kepada Tim Dosen dan Asisten serta rekan-rekan Kuliah Kerja Lapangan III Departemen Geografi Lingkungan UGM Tahun 2018 yang telah mendampingi proses penelitian dan tempat berdiskusi.

\section{PERTANYAAN KONTRIBUSI PENULIS}

Kontribusi masing-masing terhadap pembuatan karya tulis dengan judul Analisis Dampak Minapolitan Terhadap Kesejahteraan Masyarakat $\mathrm{Di}$ Kecamatan Muncar Kabupaten Banyuwangi (Studi Kasus: Desa Tembokrejo dan Kedungrejo) ini adalah Sri Rahayu Budiani sebagai kontributor utama dan Putri Kartika Sari, Muthia Hasna Thifaltanti, Regina Lexi Narulita, Reviana Latifah, Prameswari Budi Kusumaningrum, Nourma Linda Isnastuti, Rivan Agung Triawan, dan Dicky Satria Dwiputra sebagai kontributor anggota.

\section{DAFTAR PUSTAKA}

Agustine, A. D. (2017). Perencanaan Strategis Pengembangan Minapolitan (Studi di Desa Kemangi, Kecamatan Bungah, Kabupaten Gresik. Jurnal IImu Administrasi Publik, 2(1), 44-49. https://doi.org/10.15713/ins.mmj.3

Asbudi. (2013). Pemanfaatan Wilayah Pesisir oleh Masyarakat Nelayan Togo Ganda di Desa Pegat Batumbuk Kecamatan Pulau Derawan Kabupaten Berau. Jurnal Beraja Niti, Vol, 2(4).

Badan Pusat Statistik. (2015). Indikator Kesejahteraan Rakyat 2015. Jakarta: Badan Pusat Statistik.

Badan Pusat Statistik. (2017a). Indikator Kesejahteraan Masyarakat (Inkersa). Jakarta: Badan Pusat Statistik.

Badan Pusat Statistik. (2017b). Statistik Sumber Daya Laut dan Pesisir. Jakarta: Badan Pusat Statistik.

Badan Pusat Statistik Kabupaten Banyuwangi. (2017). Kecamatan Muncar dalam Angka 2017. (Badan Pusat Statistik, Ed.). Kabupaten Banyuwangi: Badan Pusat Statistik. 
Bastian, I., Winardi, R. D., \& Fatmawati, D. (2018). Metoda Wawancara. In Metoda Pengumpulan dan Teknik Analisis Data (pp. 53-99). Yogyakarta: Andi.

BKKBN. (2011). Batasan dan Pengertian MDK. Diakses pada tanggal 3 Oktober 2018 melalui http:// aplikasi.bkkbn.go.id/mdk/BatasanMDK.aspx

Dinas Pariwisata dan Kebudayaan Kabupaten Banyuwangi. (2017). Guide Book Banyuwangi Tourism. Diakses pada tanggal 3 Oktober 2018, darihttps://banyuwangitourism.com/public/ frontend_assets/images/Guide $\% 20$ Book $\% 20$ Banyuwangi\%20Tourism.pdf.

Fatimah, D., Sunartomo, A., \& Mustapit. (2014). Strategi Mata Pencaharian Rumah Tangga Nelayan Akibat Perubahan Iklim di Kecamatan Muncar Kabupaten Banyuwangi. Jurnal Berkala IImiah Pertanian, Vol. 10 (10)

Ibrahim. (2015). Metodologi Penelitian Kualitatif: Panduan Penelitian beserta Contoh Proposal Kualitatif. Pontianak: Perpustakaan Nasional

Kamuli, S. (2014). Evaluasi tentang Implementasi Kebijakan Pengembangan Kawasan Minapolitan di Kabupaten Gorontalo Utara. Mimbar, 30(1), 53-61.

Kusnadi. (2002). Konflik sosial nelayan : kemiskinan dan perebutan sumber daya perikanan. Yogyakarta. LKiS.

Munaf, D. R., \& Windari, R. (2015). Pengembangan Sumberdaya Kelautan dalam Industri Maritim Dunia. Jurnal Sosioteknologi, 14(2), 154-159.

Peraturan Daerah Kabupaten Banyuwangi Nomor 08 Tahun 2012 Tentang Rencana Tata Ruang Wilayah Kabupaten Banyuwangi Tahun 2012-2032. Diakses pada tanggal 21 Agustus 2018, dari http://peraturan.go.id/perda/kabupaten-banyuwangi-nomor-8-tahun-2012-11e452bdb 36739a0b67b313634353433.html.

Peraturan Menteri Kelautan dan Perikanan Republik Indonesia Nomor PER.12/MEN/2010 tentang Minapolitan. Diakses pada tanggal 21 Agustus 2018, dari http://www.ppk-kp3k.kkp.go.id/ver3/ media/download/RE_peraturan-menteri-kelautan-dan-perikanan-republik-indonesia-nomor-per -12-men-2010-_20141008123744.pdf.

Rosni. (2017). Analisis Tingkat Kesejahteraan Masyarakat Nelayan di Desa Dahari Selebar Kecamatan Talawi Kabupaten Batubara. Jurnal Geografi, 9(1), 53-66.

Saleha, Q. (2013). Kajian Struktur Sosial dalam Masyarakat Nelayan di Pesisir Kota Balikpapan. Buletin PSP, 21(1), 67-75.

Salim, M. (2013). Dinamika Kebijakan Kelautan dan Perikanan Kabupaten Rembang pada Masa Reformasi Tahun 1998-2008. Jurnal Sejarah Citra Lekha, 17(1), 67-84.
Wiratama, A. (2016). Dampak Implementasi Program Minapolitan terhadap Kesejahteraan Masyarakat di Kecamatan Muncar Kabupaten Banyuwangi. Kebijakan Dan Manajemen Publik, 4(3).

Zulkarnain, M., Purwanti, P., \& Indrayani, E. (2013). Analisis Pengaruh Nilai Produksi Perikanan Budidaya terhadap Produk Domestik Bruto Sektor Perikanan di Indonesia. Jurnal ECSOFiM, 1(1). 